University of Nebraska - Lincoln

DigitalCommons@University of Nebraska - Lincoln

USDA National Wildlife Research Center - Staff Publications
U.S. Department of Agriculture: Animal and Plant Health Inspection Service

2018

\title{
Nutritional depletion of total mixed rations by red-winged blackbirds and projected impacts on dairy cow performance
}

\author{
James C. Carlson \\ USDA APHIS Wildlife Services, james.c.carlson@aphis.usda.gov \\ Randal S. Stahl \\ USDA APHIS Wildlife Services \\ John J. Wagner \\ Colorado State University \\ Terry E. Engle \\ Colorado State University \\ Shelagh T. DeLiberto \\ USDA APHIS Wildlife Services, shelagh.t.deliberto@usda.gov
}

See next page for additional authors

Follow this and additional works at: https://digitalcommons.unl.edu/icwdm_usdanwrc

Part of the Life Sciences Commons

Carlson, James C.; Stahl, Randal S.; Wagner, John J.; Engle, Terry E.; DeLiberto, Shelagh T.; Reid, Dustin A.; and Werner, Scott J., "Nutritional depletion of total mixed rations by red-winged blackbirds and projected impacts on dairy cow performance" (2018). USDA National Wildlife Research Center - Staff Publications. 2172.

https://digitalcommons.unl.edu/icwdm_usdanwrc/2172

This Article is brought to you for free and open access by the U.S. Department of Agriculture: Animal and Plant Health Inspection Service at DigitalCommons@University of Nebraska - Lincoln. It has been accepted for inclusion in USDA National Wildlife Research Center - Staff Publications by an authorized administrator of DigitalCommons@University of Nebraska - Lincoln. 
Authors

James C. Carlson, Randal S. Stahl, John J. Wagner, Terry E. Engle, Shelagh T. DeLiberto, Dustin A. Reid, and Scott J. Werner 


\title{
Nutritional depletion of total mixed rations by red-winged blackbirds and projected impacts on dairy cow performance
}

\author{
James C. Carlson ${ }^{1}$, Randal S. Stahl ${ }^{1}$, John J. Wagner ${ }^{2}$, Terry E. Engle ${ }^{2}$, Shelagh T. DeLiberto ${ }^{1}$, \\ Dustin A. Reid ${ }^{1}$ and Scott J. Werner ${ }^{1 *}$ \\ 'U.S. Department of Agriculture, Animal and Plant Health Inspection Service, Wildlife Services, National Wildlife Research Center, \\ 4101 LaPorte Avenue, Fort Collins, Colorado, USA \\ 2Department of Animal Science, Colorado State University, College of Agricultural Sciences, Fort Collins, Colorado, USA
}

Received 2 November 2017; accepted for publication 15 June 2018

\begin{abstract}
This Research Communication describes an investigation of the nutritional depletion of total mixed rations (TMR) by pest birds. We hypothesized that species-specific bird depredation of TMR can alter the nutritional composition of the ration and that these changes can negatively impact the performance of dairy cows. Blackbirds selected the high energy fraction of the TMR (i.e., flaked corn) and reduced starch, crude fat and total digestible nutrients during controlled feeding experiments. For Holsteins producing $37 \cdot 1 \mathrm{~kg}$ of milk/d, dairy production modeling illustrated that total required net energy intake $\left(\mathrm{NE}_{1}\right)$ was $35.8 \mathrm{Mcal} / \mathrm{d}$. For the reference TMR unexposed to blackbirds and the blackbird-consumed TMR, NE supplied was 41.2 and $37.8 \mathrm{Mcal} / \mathrm{d}$, and the resulting energy balance was 5.4 and $2.0 \mathrm{Mcal} / \mathrm{d}$, respectively. Thus, Holsteins fed the reference and blackbird-consumed TMR were estimated to gain one body condition score in 96 and $254 \mathrm{~d}$, and experience daily weight change due to reserves of 1.1 and $0.4 \mathrm{~kg} / \mathrm{d}$, respectively. We discuss these results in context of an integrated pest management program for mitigating the depredation caused by pest birds at commercial dairies.
\end{abstract}

Keywords: Agelaius phoeniceus, dairy production, bird damage management, nutrition.

Multiple species of cohabitant birds, including red-winged blackbirds (Agelaius phoeniceus) and European starlings (Sturnus vulgaris), congregate in large flocks and exploit the abundant and nutritious food sources found at dairies and feedlots (Besser et al. 1968; Dolbeer et al. 1978). Estimates of bird damage in commercial dairies in Wisconsin, New York and Pennsylvania suggest that redwinged blackbirds were one of the most common birds species associated with depredation (Shwiff et al. 2012). Red-winged blackbirds have been previously observed to most frequently consume corn, averaging 30\% of their diet (White et al. 1985). In contrast, European starlings offered individual components of total mixed rations (TMR) preferentially selected Propel ${ }^{\circledR}$ energy nugget (Nestle Purina, St. Louis, Missouri, USA), averaging $49 \%$ of their daily diet (Carlson et al. 2018).

The purpose of this study was to investigate the nutritional depletion of TMR by red-winged blackbirds and their associated impacts to dairy production. We previously estimated

*For correspondence; e-mail: Scott.J.Werner@aphis.usda.gov the nutritional depletion of TMR by European starlings (Carlson et al. 2018). Our estimates from the NRC (2001) production model suggested that cows fed TMR exposed to starlings would lose one body condition score (BCS) in $91 \mathrm{~d}$ and cows fed the reference TMR (unexposed to starling depredation) would lose one BCS in $161 \mathrm{~d}$ (Carlson et al. 2018). We hypothesized that species-specific bird depredation of TMR can alter the nutritional composition of the ration and that these changes can negatively impact the performance of dairy cows. We therefore replicated our controlled feeding experiment and dairy production modeling with red-winged blackbirds offered individual TMR components and a high-energy TMR to investigate the nutritional depletion of dairy rations by red-winged blackbirds and the associated impacts on dairy cow performance.

\section{Materials and methods}

We conducted a controlled feeding experiment with redwinged blackbirds offered individual TMR components. On each of four test days, we offered blackbirds within 
group cages ( $n=10$ cages; five birds per cage) $100 \mathrm{~g}$ of eight individual TMR components including steamed-flaked corn, Propel ${ }^{\circledR}$ energy nugget, canola meal, cracked corn, ground corn, soybean meal, cotton seed and lactating mineral. All components were sourced from a commercial dairy located in Larimer County, Colorado 80538. Blackbird consumption of individual TMR components is reported as percent consumed throughout the 4-d test. The live-capture, animal care and use procedures were approved by the Institutional Animal Care and Use Committee of the National Wildlife Research Center (QA-2369, J.C. CarlsonStudy Director).

For the purpose of estimating the nutritional offsets caused by red-winged blackbirds, we subsequently offered a high energy TMR (30-160 d in milk) to experimentally-naïve blackbirds within group cages $(n=10$ cages; 5 birds per cage, $1 \mathrm{~kg}$ TMR per cage) for four consecutive days. Parameterization of the dairy production model (NRC, 2001) was based upon animal condition and feed formulation data provided by a commercial dairy in northern Colorado, nutrition data provided by Cumberland Valley Analytical Services (CVAS, Hagerstown, Maryland USA) and our component preference data.

All nutritional data were analyzed using ANOVA within mixed linear models (Proc Mixed, SAS 9.2, SAS Institute Inc., Cary, North Carolina USA). Fixed effects included treatment status (i.e., reference and blackbird-consumed rations) and cage was included as a random effect. Denominator degrees of freedom were calculated using the Satterthwaite approximation. We controlled for false discoveries using the Benjamini-Hochberg procedure (Benjamini \& Hochberg, 1995). For all analyses, the false discovery rate was set at $\alpha=0 \cdot 05$. Univariable analyses were ranked by $P$ value from smallest $(1)$ to largest $(m)$. Cutoff values for the rejection of null hypotheses were calculated as $(\mathrm{rank} / m) \times \alpha$.

\section{Results and discussion}

Red-winged blackbirds preferred TMR components with high starch and high fat content. Among all foods consumed, various corn products (flaked, cracked and ground corn) accounted for $78 \%$ of all foods consumed by redwinged blackbirds during the preference experiment. Blackbirds primarily consumed flaked corn $(42 \%)$ and the energy nugget $(13 \%)$, and cracked corn and ground corn comprised 4 and $1 \%$ of blackbird consumption, respectively. Each of the other TMR components comprised $<0.5 \%$ of blackbird consumption. Thus, blackbirds are likely attracted to concentrated animal feeding operations because of specific nutrients associated with expensive feed components (e.g., processed corn, fat supplements).

The preference and consumption of various TMR components by pest birds may significantly alter the cost to producers and the decision-making for bird damage management. The preference of red-winged blackbirds for steamflaked corn $(42 \%$ consumption) was greater than that observed for Prope ${ }^{\circledR}$ energy nugget, canola meal, cracked corn, ground corn, soybean meal, cotton seed and lactating mineral. In contrast, the preference of European starlings for Prope $^{\circledR}$ energy nugget ( $49 \%$ consumption) was greater than that observed for steam-flaked corn, corn gluten, dry distillers grains, canola meal, corn silage and mineral supplement (Carlson et al. 2018). Thus, species-specific data for offending bird species are necessary for (1) the generation of accurate estimates of bird damage and (2) the prescription and implementation of cost-effective damage management strategies.

The nutritional data illustrated that red-winged blackbird consumption significantly altered the nutritional characteristics of TMR (Table 1). Relative to the reference rations unexposed to blackbirds, blackbird-consumed rations had less net energy for lactation $(P<0 \cdot 0001)$, maintenance $(P<$ $0 \cdot 0001)$ and gain $(P<0 \cdot 0001)$. Blackbird-consumed rations also had lower concentrations of starch $(P<0 \cdot 0001)$, crude fat $(P<0.0001)$ and total digestible nutrients $(P<0.0001)$, and greater concentrations of acid detergent fiber $(P<$ $0 \cdot 0017)$, neutral detergent fiber $(P<0 \cdot 0005)$, potassium $(P<$ $0 \cdot 0001)$ and calcium $(P<0.0017)$ compared to the reference rations. Relative to reference rations, we observed a $9.5 \%$ reduction in corn silage, a $9.6 \%$ reduction in energy nugget, a $23.6 \%$ reduction in ground corn and a $24.7 \%$ reduction in steam-flaked corn in TMR exposed to red-winged blackbirds. These results enabled us to identify metabolizable energy sources that need to be excluded from depredating blackbirds.

Dairy production modeling (NRC, 2001) illustrated that cow performance can be negatively impacted by blackbird consumption of TMR (Table 2). For Holsteins producing $37.1 \mathrm{~kg}$ of milk/d, total required net energy intake $\left(N E_{1}\right)$ was $35.8 \mathrm{Mcal} / \mathrm{d}$. For the reference TMR, $\mathrm{NE}_{1}$ supplied was $41.2 \mathrm{Mcal} / \mathrm{d}$ and for the blackbird-consumed TMR NE supplied was $37 \cdot 8 \mathrm{Mcal} / \mathrm{d}$. The resulting energy balance for reference and blackbird-consumed rations was 5.4 and $2.0 \mathrm{Mcal} / \mathrm{d}$, respectively. Thus, blackbird depredation of cattle feed can reduce dairy production through the nutritional depletion of TMR.

We also observed species-specific impacts of pest birds on dairy cow performance. Body condition scores integrate the influences of many nutritional aspects of TMR to distinguish differences in the fat reserves, or the nutritional needs among individual cows. The high-energy reference TMR used for this blackbird experiment would cause the gain of one BCS in $96 \mathrm{~d}$ ( $v s .255 \mathrm{~d}$ for the blackbird-exposed TMR; Table 2) for cows producing $37 \cdot 1 \mathrm{~kg}$ of milk per day $\left(\mathrm{NE}_{\mathrm{l}}=35.8 \mathrm{Mcal} / \mathrm{d}\right)$. In contrast, the late-lactation reference TMR used for our starling feeding experiments would cause the loss of one BCS in $161 \mathrm{~d}$ (vs. $91 \mathrm{~d}$ for the starling-exposed TMR) for cows producing $31.75 \mathrm{~kg}$ of milk per day $\left(\mathrm{NE}_{\mathrm{l}}=31.5 \mathrm{Mcal} / \mathrm{d}\right.$; Carlson et al. 2018). These TMR-specific differences notwithstanding, the absolute difference in BCS was $159 \mathrm{~d}$ in this blackbird study and $70 \mathrm{~d}$ in the starling study (Carlson et al. 2018). Because fat supplements are approximately $\$ 1 \cdot 10$ per $\mathrm{kg}$ (USD) and corn products are approximately $\$ 0 \cdot 14$ per $\mathrm{kg}$, we conclude that starlings can have a greater monetary impact to dairy 
Table 1. Nutritional analysis of reference and blackbird-consumed total mixed rations

\begin{tabular}{|c|c|c|c|c|c|c|}
\hline Variable & Metric & Reference mean $(X)$ & Blackbird mean $(X)$ & $P$-value & $\operatorname{Rank}^{\dagger}$ & Cutoff value ${ }^{*}$ \\
\hline Net Energy Lactation & Mcal/kg & $1 \cdot 839$ & $1 \cdot 700$ & $<0 \cdot 0001$ & $4 \cdot 5$ & $0 \cdot 0102$ \\
\hline Net Energy Maintenance & $\mathrm{Mcal} / \mathrm{kg}$ & $1 \cdot 825$ & $1 \cdot 739$ & $<0 \cdot 0001$ & $4 \cdot 5$ & $0 \cdot 0102$ \\
\hline Net Energy Gain & $\mathrm{Mcal} / \mathrm{kg}$ & $1 \cdot 197$ & $1 \cdot 120$ & $<0 \cdot 0001$ & $4 \cdot 5$ & $0 \cdot 0102$ \\
\hline Starch & $\% D M$ & $31 \cdot 128$ & $28 \cdot 221$ & $<0 \cdot 0001$ & $4 \cdot 5$ & $0 \cdot 0102$ \\
\hline Crude Fat & $\% D M$ & $5 \cdot 482$ & $4 \cdot 625$ & $<0 \cdot 0001$ & $4 \cdot 5$ & $0 \cdot 0102$ \\
\hline Potassium & $\% D M$ & $1 \cdot 159$ & $1 \cdot 252$ & $<0 \cdot 0001$ & $4 \cdot 5$ & $0 \cdot 0102$ \\
\hline Total Digestible Nutrients & $\% D M$ & $76 \cdot 184$ & $73 \cdot 459$ & $<0 \cdot 0001$ & $4 \cdot 5$ & $0 \cdot 0102$ \\
\hline Non Fiber Carbohydrates & $\% D M$ & $42 \cdot 634$ & $40 \cdot 25$ & $<0 \cdot 0001$ & $4 \cdot 5$ & $0 \cdot 0102$ \\
\hline Neutral Detergent Fiber & $\% D M$ & $24 \cdot 825$ & $26 \cdot 725$ & $0 \cdot 0005$ & $9 \cdot 0$ & 0.0205 \\
\hline Acid Detergent Fiber & $\% D M$ & $16 \cdot 134$ & $17 \cdot 793$ & $0 \cdot 0017$ & $10 \cdot 5$ & $0 \cdot 0239$ \\
\hline Calcium & $\% D M$ & $1 \cdot 179$ & $1 \cdot 283$ & $0 \cdot 0017$ & $10 \cdot 5$ & $0 \cdot 0239$ \\
\hline Ash & $\% D M$ & $7 \cdot 724$ & $8 \cdot 195$ & $0 \cdot 002$ & 12 & $0 \cdot 0273$ \\
\hline Crude Protein & $\% D M$ & $19 \cdot 347$ & $20 \cdot 203$ & $0 \cdot 0028$ & 13 & 0.0295 \\
\hline Phosphorus & $\% D M$ & $0 \cdot 448$ & $0 \cdot 468$ & $0 \cdot 0031$ & 14 & $0 \cdot 0318$ \\
\hline Copper & PPM & $30 \cdot 282$ & $31 \cdot 938$ & $0 \cdot 0073$ & 15 & $0 \cdot 0341$ \\
\hline Magnesium & $\% D M$ & $0 \cdot 376$ & $0 \cdot 396$ & $0 \cdot 0317$ & 16 & 0.0364 \\
\hline Manganese & PPM & $136 \cdot 125$ & $142 \cdot 373$ & $0 \cdot 0356$ & 17 & $0 \cdot 0386$ \\
\hline Zinc & PPM & $253 \cdot 186$ & $279 \cdot 656$ & $0 \cdot 0691$ & 18 & $0 \cdot 0409$ \\
\hline Dry Matter & $\% D M$ & $96 \cdot 409$ & $96 \cdot 543$ & $0 \cdot 1994$ & $19 \cdot 5$ & $0 \cdot 0443$ \\
\hline Moisture & $\% D M$ & $3 \cdot 591$ & $3 \cdot 456$ & $0 \cdot 1994$ & $19 \cdot 5$ & $0 \cdot 0443$ \\
\hline Sodium & $\% D M$ & $0 \cdot 444$ & 0.451 & 0.4531 & 21 & 0.0477 \\
\hline Iron & PPM & $361 \cdot 218$ & $361 \cdot 531$ & 0.9863 & 22 & $0 \cdot 05$ \\
\hline
\end{tabular}

$\dagger$ Rank order of $P$-values from analyses of nutritional cattle feed samples $\ddagger$ Benjamini Hochberg cutoff values for rejection of null hypotheses

Table 2. National Research Council, dairy production model output for reference and blackbird-consumed total mixed rations

\begin{tabular}{|c|c|c|}
\hline NRC model output ${ }^{\dagger}$ & $\begin{array}{l}\text { Reference } \\
\text { TMR }\end{array}$ & $\begin{array}{l}\text { Blackbird-consumed } \\
\text { TMR }\end{array}$ \\
\hline $\mathrm{NE}_{\mathrm{I}}$ required $(\mathrm{Mcal} / \mathrm{d})$ & $35 \cdot 8$ & $35 \cdot 8$ \\
\hline NE supplied (Mcal/d) & $41 \cdot 2$ & $37 \cdot 8$ \\
\hline $\mathrm{NE}_{\mathrm{l}}$ balance $(\mathrm{Mcal} / \mathrm{d})$ & $5 \cdot 4$ & $2 \cdot 0$ \\
\hline Days to gain one BCS & 96 & 255 \\
\hline Weight change (kg/d) & $1 \cdot 1$ & $0 \cdot 4$ \\
\hline RDP required $(\mathrm{g} / \mathrm{d})$ & 2541 & 2312 \\
\hline RDP supplied (g/d) & 2584 & 2524 \\
\hline RDP balance (g/d) & 42 & 212 \\
\hline RUP required (g/d) & 1300 & 1395 \\
\hline RUP supplied (g/d) & 1853 & 1689 \\
\hline RUP balance (g/d) & 552 & 294 \\
\hline MP - bacterial (g/d) & 1383 & 1258 \\
\hline$M P-R U P(g / d)$ & 1447 & 1305 \\
\hline $\mathrm{MP}$ - endogenous $(\mathrm{g} / \mathrm{d})$ & 120 & 109 \\
\hline
\end{tabular}

$\dagger$ RDP and RUP are rumen degradable protein and rumen undegradable protein, respectively. MP is microbial protein

production than red-winged blackbirds. We have previously observed the colonization of thousands of blackbirds subsequent to the lethal control of starlings at particular dairies. Thus, the impacts of pest birds and the cost-effective management associated with these impacts are dependent on the species composition and the density of the pest-bird community at a particular dairy operation.

Because pest birds may not nutritionally deplete all TMR consumed by cows each day (Carlson et al. 2018), our results may overestimate the nutritional depletion caused by blackbirds at commercial dairies. The density of blackbirds in our controlled feeding experiments is comparable to more than 100 blackbirds per cow under field conditions. Most commercial dairies will likely not experience 100 pest birds per cow nor the associated extent of nutritional depletion as estimated by our study. Our approach and our results, however, demonstrate that (1) we can estimate the species-specific nutritional depletion caused by pest birds and (2) dairy production models can be used to predict production losses to dairies impacted by bird depredation.

Similar to European starlings (Glahn et al. 1983), red-winged blackbirds are apparently influenced by the form and size of livestock feed. For example, blackbirds strongly preferred flaked corn over ground corn in our feeding experiments. Previous research has shown that European starlings could not consume $\geq 1 \cdot 27 \mathrm{~cm}$-diameter (Depenbusch et al. 2011) extruded feed pellets. Altering the size of flaked corn and fat nugget, or combining highly desired components into approximately $1.27 \mathrm{~mm}$-diameter pellets or finely milled particles may be a non-lethal component of integrated pest management strategies for the mitigation of the species-specific impacts of bird depredation (Twedt \& Glahn, 1982; Glahn et al. 1983; Depenbusch et al. 2011; Carlson et al. 2018).

\section{References}

Benjamini Y \& Hochberg Y 1995 Controlling for false discovery rate: a practical and powerful approach to multiple testing. Journal of the Royal Statistical Society $\mathbf{5 7}$ 289-300 
Besser JF, DeGrazio JW \& Guarino JL 1968 Costs of wintering starlings and red-winged blackbirds at feedlots. Journal of Wildlife Management 32 179-180

Carlson JC, Stahl RS, DeLiberto ST, Wagner JJ, Engle TE, Engeman RM, Olson CS, Ellis JW \& Werner SJ 2018 Nutritional depletion of total mixed rations by European starlings: projected effects on dairy cow performance and potential intervention strategies to mitigate damage. Journal of Dairy Science 101 1777-1784

Depenbusch BE, Drouillard JS \& Lee CD 2011 Feed depredation by European starlings in a Kansas feedlot. Human-Wildlife Interactions $\mathbf{5}$ 58-65

Dolbeer RA, Wornecki PA, Strickley JR \& White SB 1978 Agricultural impact of a winter population of blackbirds and starlings. Wilson Bulletin $9031-44$
Glahn JF, Twedt DJ \& Otis DL 1983 Estimating feed loss from starling use of livestock feed troughs. Wildlife Society Bulletin 11 366-372

National Research Council (NRC) 2001 Nutrient Requirement of Dairy Cattle, Seventh edition. National Research Council, National Academy Press, Washington, DC

Shwiff SA, Carlson JC, Glass H, Suckow J, Lowney MS, Moxcey KM, Larson B \& Linz GM 2012 Producer survey of bird livestock interactions in commercial dairies. Journal of Dairy Science 95 6820-6829

Twedt DJ \& Glahn JF 1982 Reducing starling depredation at livestock feeding operations through changes in management practices. Proceedings of the Vertebrate Pest Conference 10 159-163

White SB, Dolbeer RA \& Bookhout TA 1985 Ecology, bioenergetics, and agricultural impacts of a winter-roosting population of blackbirds and starlings. Wildlife Monographs 93 1-42 